\title{
An Investigation Of The Erosion In New Major Innovation Characteristics Over Time
}

Joseph B. O’Donnell, Canisius College, USA

Paul L. Sauer, Canisius College, USA

\begin{abstract}
A recent study by O'Donnell and Sauer (2008) indicated, that over time, the benefit of launching new majors to reduce freshman attrition dissipated. In 2004, new majors had a significant effect on reducing attrition. By 2007, however, these same new majors were no longer significant predictors of attrition. What happened between 2004 and 2007 to cause this erosion in the affect of new majors on attrition? In this study, we examine the differences in perceptions of the innovative characteristics in an effort to explain why this erosion might have occurred. Results of a two-way between subjects ANOVA reveals that new majors began to be perceived as similar to old majors along certain dimensions of innovative characteristics. In particular, differences in the prospects of getting a better job, the perception that the new major was easier, hearing from others that new majors offered better job prospects and that employers preferred new majors, and that new majors were less compatible with student needs and goals, all disappeared by 2007. Nevertheless, new majors were still perceived as requiring more prerequisites, being more likely to require an extra course, and as not being offered at other area colleges and universities relative to old majors. This article discusses the impact and consequences of these findings and proposes future research to be pursued.
\end{abstract}

Keywords: Innovation Characteristics, Newness of Innovation, Educational Innovations, Factor Analysis, ANOVA, Higher Education, Student Retention, Relative Advantage

\section{INTRODUCTION}

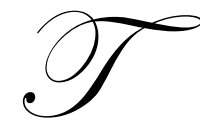

he relevance of the newness of products to increasing adoption, and hence sales, has been well documented in the literature (Dewett and Williams 2007). Corporate strategy often focuses on new product development and launch as the key to sustained sound financial performance (Klepper 1996; Shapiro 2006). Thinking as to how new product launches may cannibalize existing product offerings may change the strategy from an avoidance to an achievement goal (Ghemawat 1991; Mashey 2009). Intel, for example, launches new computer chips with the goal of cannibalizing their existing offerings before a competitor can (Golda and Philippi 2007; Mutschler 2008). New products may this relevant to not only the financial health of the firm, but also to the existence of the firm (Reinganum 1985; Schmidt and Druehl 2005). But a question remains as to how long a new product is perceived by consumers as "new" and hence desirable. Is it a function of competition launching new and improved products, or does the newness simply wear off with time? This question is relevant to all organizations launching new products and services, including educational institutions that launch new majors.

In a recent article O'Donnell and Sauer (2008) show that educational institutions that launch new majors may influence the retention rate of freshman students, but that over time, this effect wears off. A question remains, however, as to what facets of the innovation - in this case new majors - changed as the newness effect on retention disappeared. The goal of this research is to answer this question. We begin by reviewing the literature relevant to new product innovation characteristics. We next review the work that has been done in this area relevant to the launch of new majors by colleges and universities. We then describe the nature of the methodology used in our study to determine possible perceptions of the new majors that simultaneously changed as the newness wore off. We finish with a discussion of the implications of our finding for future research and for strategies that colleges and universities should consider in deciding whether or not to launch new majors. 


\section{BACKGROUND}

"An innovation is defined as "an idea, practice, or object that is perceived as new by an individual" (Rogers, 2003 p. 12). Adoption of innovations is a vast research area that has focused on topics, such as the characteristics of the innovation, the rate of adoption, the influence of the social network, and the characteristics of the innovator (Rogers, 2003). Consistent with other innovations, these research areas are relevant to educational innovations. For instance, new programs and majors should be designed with regard to student perceptions of the major's benefits and attributes

There is a rich tradition of research in the acceptance and diffusion of educational innovations that dates back to the 1920's (Rogers, 2003). Many of the studies have focused on the rate at which different educational innovations have been adopted by educators. Some examples of educational innovation studies are diffusion of modern math (Ready, 1992), worldwide diffusion of kindergarten (Wollons, 2000), educational use of technology (Frank et al., 2004), and online marketing of educational programs (Gomes \& Murphy, 2003). Prior research has shown that new academic majors are associated with positive student perceptions (Sauer and O'Donnell, 2007) and increased student retention (Sauer and O'Donnell, 2006). Scales addressing perceptions of innovations have been developed and applied to numerous innovations (Rogers, 2003).

While studies of the perceptions of new innovations have shed light on the reasons for adopting products, there are opportunities to investigate whether these perceptions persist and, in turn, the success of the innovation continues. Market pioneers are those organizations which are the first to the market place with innovative products and services. Being a market pioneer offers potential opportunities for sustained producer-based, market share and consumer-based advantages (Rettie, Hiller, and Alpert, 2002). The latter is of interest to this study. Consumer-based advantages relate to consumers' attitudes, preferences and experiences regarding pioneer brands (Rettie, Hiller, and Alpert, 2002). Being the pioneer brand was found to aid in brand recall but studies indicate mixed results in regard to brand preference (Rettie, Hiller, and Alpert, 2002; Alpert and Kamins, 1995). Investigating the sustainability of perceptions of a new or innovative service would add to the understanding of the permanence of the preferences for goods and services.

\section{CHARACTERISTICS OF THE INNOVATION}

Innovation attributes have been shown to affect innovativeness (Ostlund 1974). Roehrich (2004) identifies three levels at which characteristics of the innovation may vary: (1) the general level; (2) the product level; and, (3) the domain-specific level. In reviewing innovativeness scales and their psychometric properties, Roehrich notes that most scales only identify $10 \%$ of the variance in innovative behavior, except for the scales operationalized at the domain-specific level.

It is important to distinguish between innovativeness as a characteristic of a person versus a characteristic of a product or service. Sethi, Smith and Park (2001) define innovativeness of a product as the "meaningful uniqueness" (p. 74) of the new product. Uniqueness implies both novelty and appropriateness. Rogers (2003) identifies five characteristics of products that affect adoption; (1) relative advantage; (2) compatibility; (3) trialability; (4) observability; and, (5) complexity. Courses that colleges and universities offer are intangible and therefore defined as services, not products. How then might service firms differ from firms that produce products and how might that affect adoption? How also do new majors offered by colleges and universities differ from services offered by other organizations?

While there has been some research on innovations in the service industries, the bulk of the research has tended to focus on financial products (e.g., Martin and Horne 1993; Reidenbach and Moak 1986). The shift to a service economy, however, has resulted in increased attention being paid to service firms and the unique ways in which they serve markets. Many service firms today operate in knowledge-intensive industries (Miles, Kastrinos, Flannigan, Bilderbeek, der Hertog, Hunting and Bowman 1994). Colleges and Universities are one type of knowledge-intensive firm with unique characteristics. 
The term "knowledge-intensive" imitates economists' labeling of firms as capital-intensive or laborintensive. These labels describe the relative importance of capital and labor as production inputs. In a capitalintensive firm, capital has more importance than labor; in a labor-intensive firm, labor has the greater importance. By analogy, labeling a firm as knowledge-intensive implies that knowledge has more importance than other inputs (Starbuck 1992).

In developing a physical product, a firm makes a commitment to a specific design and produces a number of these identical products. Recently developed terms, such as mass customization and flexible manufacturing reveal how products manufactured today can be tailored to more closely match the individual needs of each customer than in the past. Yet this flexibility does not come close to matching that available in service industries where the producer and deliverer of the product can make changes as the service is being consumed. In teaching a college course, for example, an instructor has the ability to change the content of the course material as the course is being delivered, even during active class sessions. The courses that are offered to majors in a field of study may change in minor or major ways from semester to semester due to faculty development, faculty attrition, etc. Major areas of study combine these always-evolving courses into a series of courses that promise to deliver a certain specific package of knowledge to a consuming student. Because of this flexible characteristic of services, the name of the new major becomes more important in selling it to prospective students. The permanence of the perceptions of those characteristics is the focus of this paper.

\section{METHODOLOGY}

\section{Sample}

Two samples were taken, one in 2004 and the second in 2007. Students in a northeastern U.S. college were asked to complete the survey instrument. The survey instrument contained multi-item five-point Likert scales designed to reflect underlying innovation constructs (Rogers, 2003). See Sauer and O'Donnell 2006 for further description of the development of the items. Student respondents were free to designate the major they would use as a base for responding to the innovation items. See O'Donnell and Sauer (2008) for a listing of survey items.

\section{Data Analysis}

The data were first factor analyzed using the Principal Axis common factor procedure with Oblique rotation in SPSS 15.0. The exploratory factor analysis (EFA) was performed separately for each of the two samples - 2004 and 2007. O'Donnell and Sauer (2008) provide a description of the results of the factor analysis. In their study, the factor scores were output to serve as input variables in a logistic regression model designed to measure the impact of choice of an innovative new major on student retention. In this study, we utilize those same factor scores. We first perform an independent samples t-test of old vs. new majors for the 2004 survey. We next examine the mean differences in a 2-way between subjects ANOVA.

The factor scores were unique to each of the two samples. In the ANOVA, the factor scores served as the dependent variables. One of the two between subject factor was the year - 2004 vs. 2007 -- in which the survey was run. The second between subjects factor was the category of major - new vs. old -- used to rate the innovativeness of the major. Ten majors were identified as new based on the number of years since they were initially offered by the college. Because education majors were not included in the sample, none of the five new education majors were used to rate the innovativeness of the major.

\section{RESULTS}

The results of the t-test of old vs. new majors using the 2004 sample data revealed that there was a significant difference for seven of the eleven factors as shown in Table 1. The results of the 2-way between subjects ANOVA are summarized in Table 2. Statistically significant results relationships were found between the 2004 and 2007 sample for the Trialability - New Major Course Prerequisite, Observability - Career Related, and the Uniqueness factors. Significant interaction effects between the 2004 and 2007 samples were identified for the Relative Advantage - Career Oriented and Observability Career Related factors. Marginally significant effects were identified for Relative Advantage-Pleasure and Compatibility with Lifestyle and Goals factors. The other five 
factors had no meaningful relationship between the 2004 and 2007 survey results. The results of the statistical factors and interactions are discussed and graphically shown below.

Table 1

T-test of Old vs New Major Factor Score Means - 2004 Survey

\begin{tabular}{|lc|}
\hline \multicolumn{1}{|c}{ Factors } & Old vs. New \\
\hline Relative Advantage - Career Oriented - Better Job & $\mathrm{X}^{* * *}$ \\
Relative Advantage - Pleasure & \\
Relative Advantage - Ease and Speed & $\mathrm{X}^{* * *}$ \\
Complexity - Difficult to Understand & \\
Complexity - Extra Course for Major & $\mathrm{X}^{* * *}$ \\
Compatibility with Lifestyle \& Goals & $\mathrm{X}^{* * *}$ \\
Trialability -- Ease of trying out & \\
Trialability -- New Major Course Pre-req & $\mathrm{X}^{* * *}$ \\
Observability -- Career Related & $\mathrm{X}^{* * *}$ \\
Observability -- Performance in Major & $\mathrm{X}^{* * *}$ \\
\hline Uniqueness & \\
\hline
\end{tabular}

Legend: $* * * \mathrm{p}<0.01 \quad * * \mathrm{p}<0.05 \quad * \mathrm{p}<0.10$

Table 2

Two-way ANOVA Results for 2004 and 2007 Samples and Significant Difference in Factor Score Means

\begin{tabular}{|c|c|c|c|c|c|}
\hline Factors & $\begin{array}{c}2004 \\
\text { Sample }\end{array}$ & $\begin{array}{c}2007 \\
\text { Sample }\end{array}$ & $\begin{array}{l}2004 \& 2007 \\
\text { Old vs. New }\end{array}$ & $\begin{array}{c}2004 \text { vs } \\
2007\end{array}$ & Interaction \\
\hline Relative Advantage - Career Oriented - Better Job & $\mathrm{X}$ & $\mathrm{X}$ & & & $\mathrm{X}^{* * *}$ \\
\hline Relative Advantage - Pleasure & $\mathrm{X}$ & $\mathrm{X}$ & & & \\
\hline Relative Advantage - Ease and Speed & $\mathrm{X}$ & $\mathrm{X}$ & & & $\mathrm{X}^{*}$ \\
\hline Complexity - Difficult to Understand & $\mathrm{X}$ & $\mathrm{X}$ & & & \\
\hline Complexity - Extra Course for Major & $\mathrm{X}$ & $X$ & $\mathrm{X}^{* * *}$ & & \\
\hline Compatibility with Lifestyle \& Goals \& Past & $\mathrm{X}$ & $\mathrm{X}$ & & & $\mathrm{X}^{*}$ \\
\hline Trialability -- Ease of trying out & $\mathrm{X}$ & $X$ & & & \\
\hline Trialability -- New Major Course Pre-req & $\mathrm{X}$ & $X$ & $\mathrm{X}^{* * *}$ & & \\
\hline Observability -- Career Related & $\mathrm{X}$ & $\mathrm{X}$ & $\mathrm{X}^{* *}$ & & $\mathrm{X}^{* *}$ \\
\hline Observability -- Performance in Major & $\mathrm{X}$ & & & & \\
\hline Uniqueness & $\mathrm{X}$ & $X$ & $\mathrm{X}^{* * * *}$ & $X^{*}$ & \\
\hline
\end{tabular}

Legend: $* * * \mathrm{p}<0.01 \quad * * \mathrm{p}<0.05 \quad * \mathrm{p}<0.10$

As shown in Figure 1, students who had seen a significant relative advantage in an old, traditional major in 2004 no longer saw that same difference in 2007. In fact, students now saw the difference as swinging toward a relative advantage of an old major. 
Figure 1

Estimated Marginal Means of Relative Advantage-1 - better job

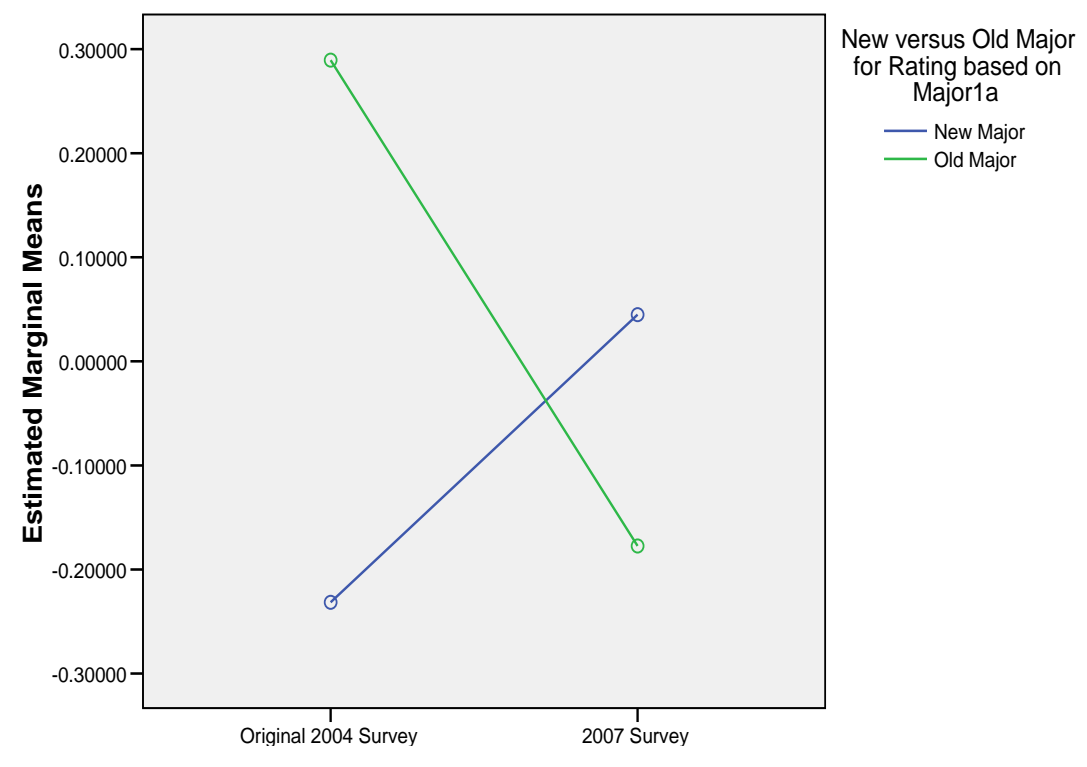

Figure 2

Estimated Marginal Means of Observability-1 -- hear better job-careeremployer prefer

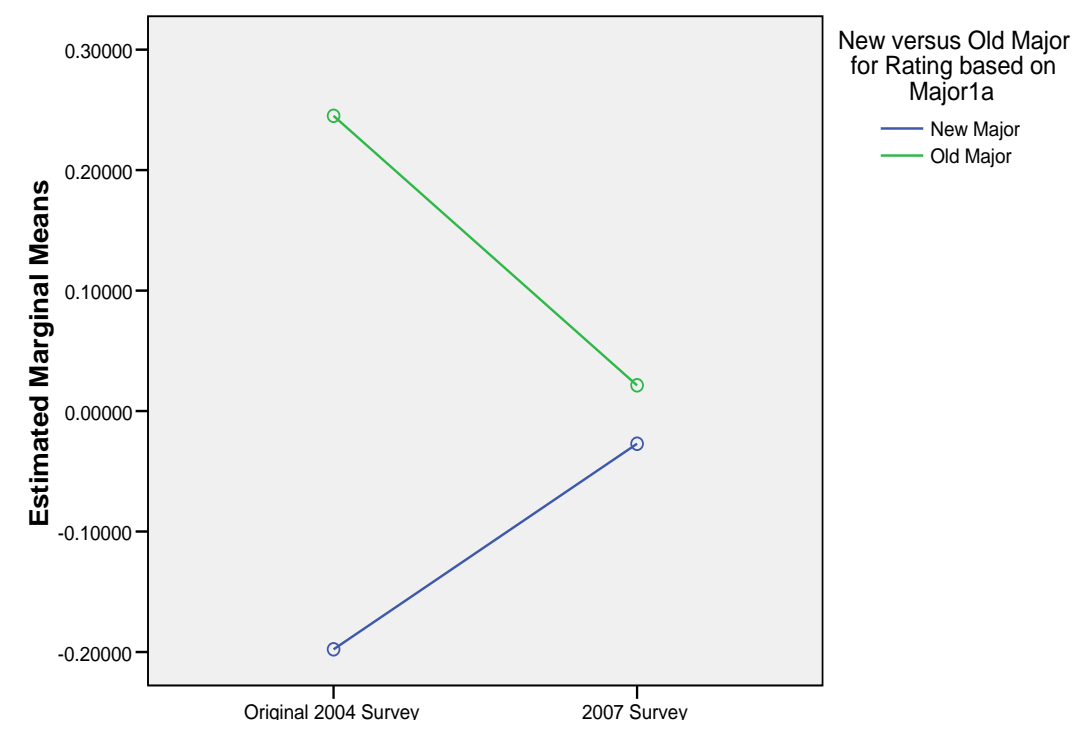

This same effect is also reflected in the interaction for hearing that an old major offered a better job and that employees prefer the old major (see Figure 2). As with the perceived relative advantage, the difference in perceived observability based on hearing about the job market disappeared by 2007. 
Figure 3

\section{Estimated Marginal Means of Relative Advantage-3 - easier}

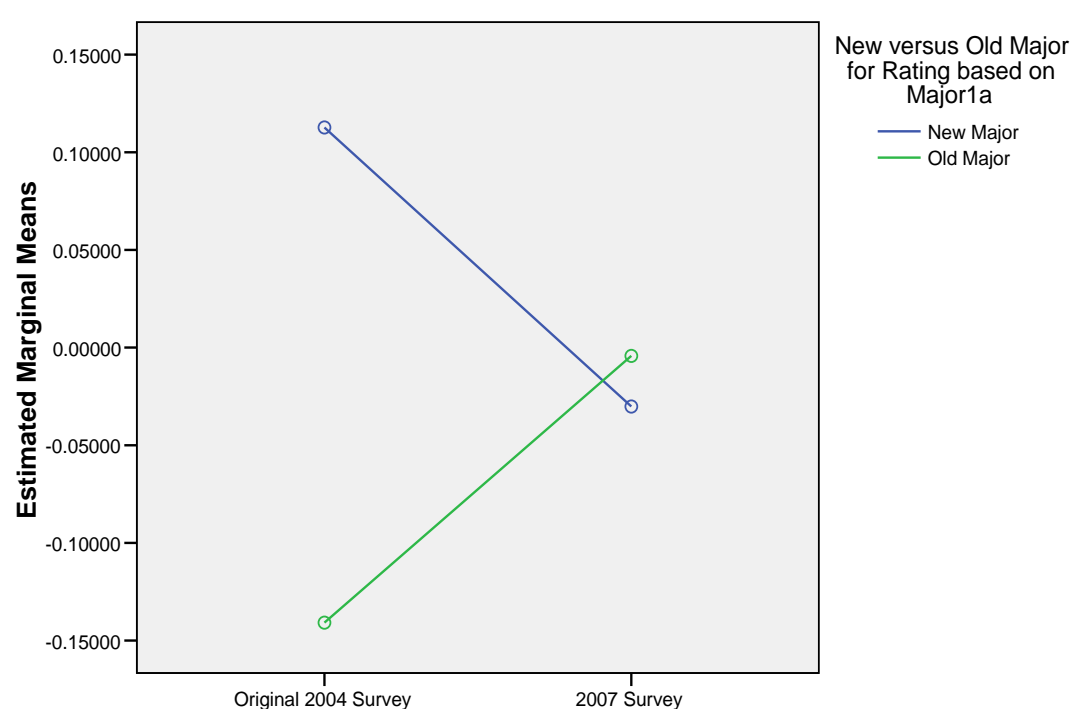

As shown in Figure 3, students who saw a relative advantage in terms of ease and speed of getting through a new major relative to an old or traditional major in 2004, no longer perceived that difference in 2007. This relationship was marginally statistically significant.

Figure 4

Estimated Marginal Means of Trial 2 - First course in major - no prerequisites

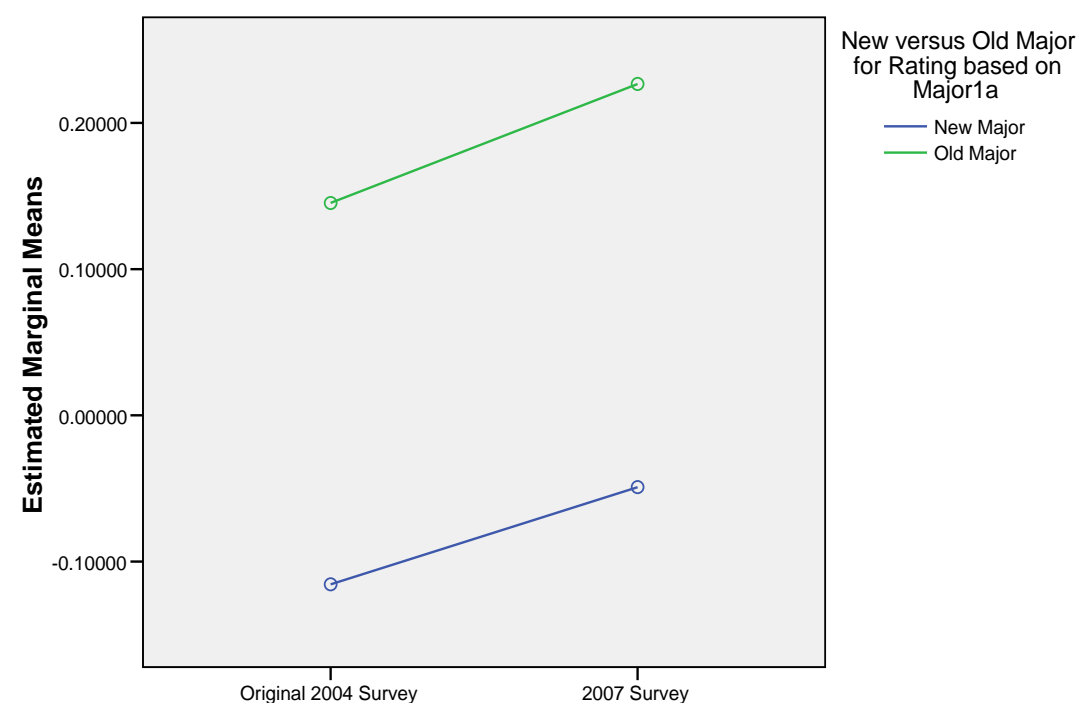

Students perceived a significant difference in trialability in 2004 in that old majors were perceived as having the first course required in the major also usable as a requisite for another major (see Figure 3). This main effect of old vs. new majors persisted in 2007. 
Figure 5

Estimated Marginal Means of Complexity-2 - need extra course for major
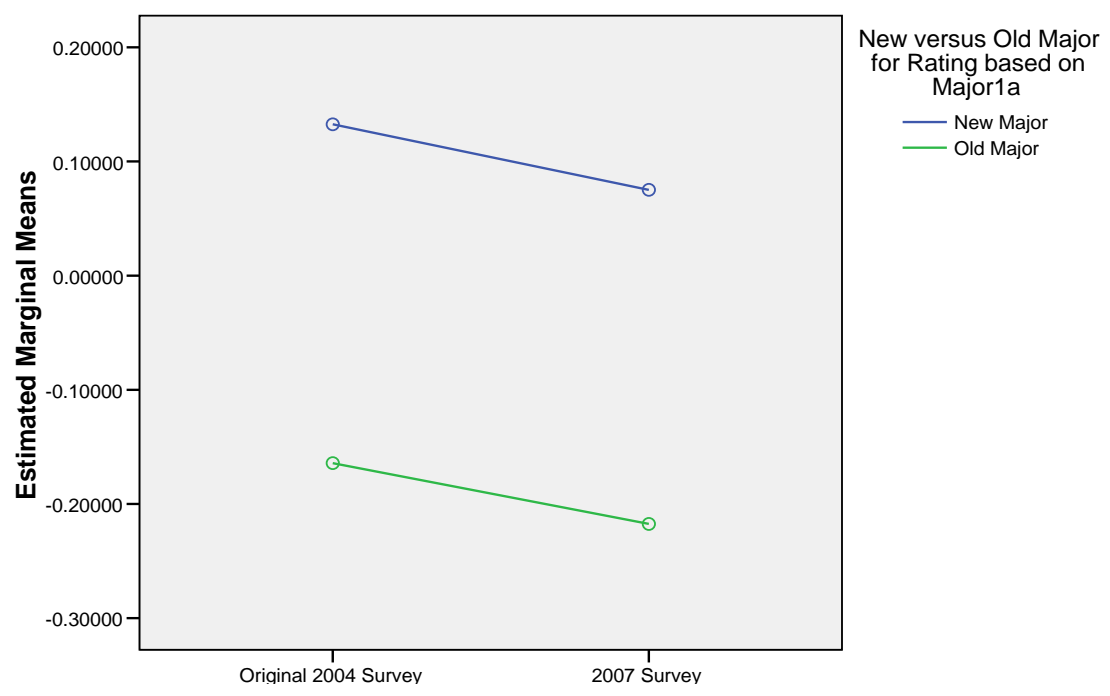

As shown in Figure 5, this same effect was also reflected in the main effect of old vs. new major on perceived complexity in that a student needed extra courses for the new major in both 2004 and in 2007. This requirement is likely due to the need for students majoring in Accounting Information Systems to also major in Accounting in order to sit for the CPA exam. The requirement of the extra courses also resulted in the perception that it was easier to do a dual major with the new major than with the old major. It is important to note that both the "required additional courses" survey item and the "easier to do a dual major" survey item loaded on this complexity factor (see O’Donnell and Sauer 2008).

\section{Figure 6}

\section{Estimated Marginal Means of Compatibility}

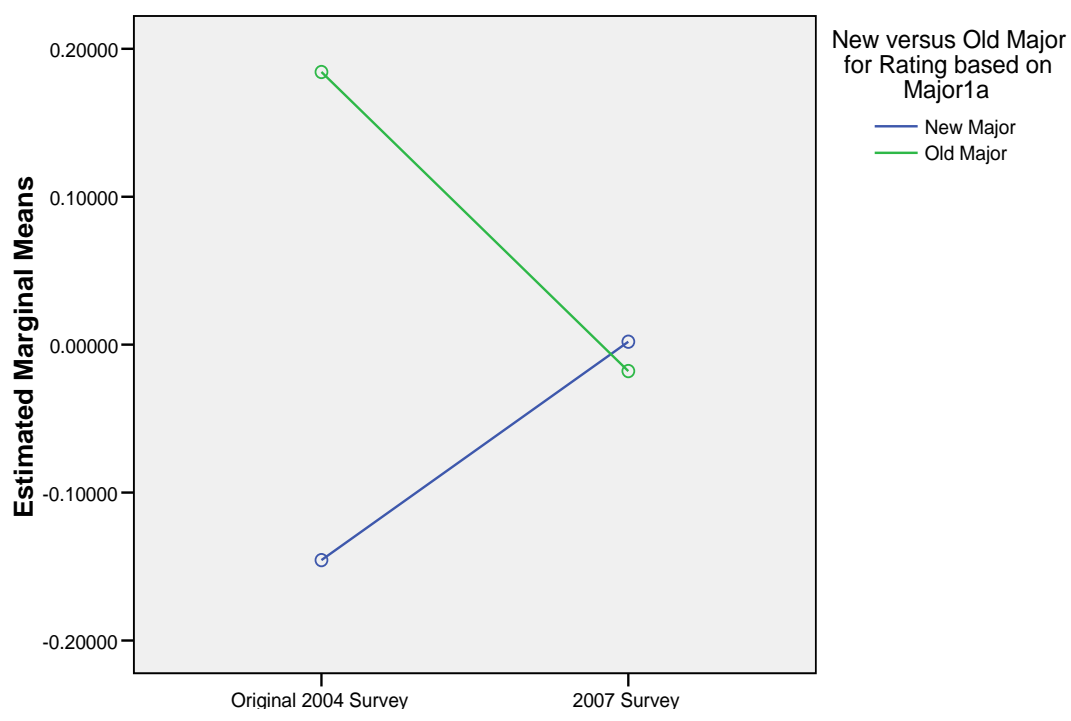


Of all the factors, compatibility was the only factor in which all of the items measuring the construct loaded on one factor. The six items all had loadings exceeding 0.7 and spanned the range of compatibility from lifestyle to academic and post graduation goals to past courses to information technology skills. A marginally significant interaction effect was observed. In 2004 the old major was perceived as being much more compatible than was the new major. By 2007 this difference had disappeared (see Figure 6).

Figure 7

Estimated Marginal Means of Uniqueness - not offered elsewhere in area

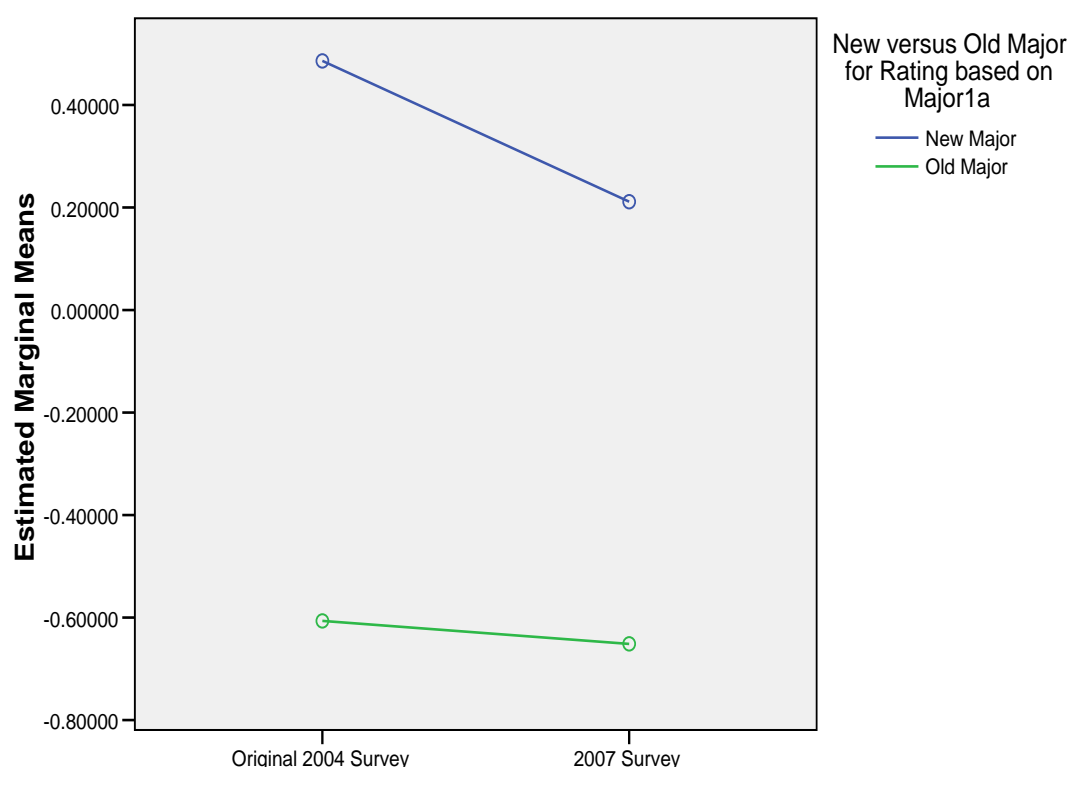

As shown in Figure 7, both the new-old and 2004-2007 factors had a significant main effect on perceived uniqueness, but there was no significant interaction effect. The new majors were perceived as not being offered elsewhere in the geographical area in which the college was located relative to the similar perception of the old majors. In 2004 the perceived uniqueness for all majors, new and old combined, was greater than the perceived uniqueness in 2007.

\section{DISCUSSION}

This study empirically reveals the decline, over time, in the differences between newly launched majors and existing, traditional majors available to college students. This decline has been observed to be a transition effect in the literature. For example, Theoharakis and Wong (2002) provide evidence in a study of the local area network (LAN) market that new product innovations go through a series of phases in which different types of information about the innovation are communicated. The movement from the second to third phase involves a transition from word-of mouth communication about the innovativeness to word-of-mouth communication about the availability of the product. This assumes that the innovative characteristics are no longer seen as innovative, but are seen as standard; hence, the competition between brands ensues. In the same sense, what we have observed in this study is that the innovativeness of the new majors has waned and the new majors are considered on par with existing majors regarding relative advantage, observability and compatibility.

This erosion of relative advantage and observability does not necessarily alter the difference in perceived uniqueness of the new major. This is because the new major is still perceived as only being available at the college where the survey was conducted and not at other area colleges or universities. It also does not affect the perception 
of which courses are required as prerequisites or the sequence of course required. These are, in a sense, the infrastructure of the new major, and though they form part of the innovation characteristics (Rogers 2003), this difference is no longer seen as unique to the innovation dimension of the new major.

In a sense, the new majors represent a brand extension form of new product introduction. In this sense, the new majors are meant to revitalize existing brands. For example, adding the International Management major is an extension of the older, traditional Management major. The Digital Media Arts major is a brand extension of the Communications Major facilitated by the launch of numerous digital technologies. Hence, they tend to serve, in a sense to revitalize the existing brands (Munthree, Bick \& Abratt 2006) and should be expected to have less of a long-term differentiating effect compared to radically new products, such as the iPhone sold by the Apple Corporation.

\section{LIMITATIONS}

Several precautions accompany this study of new majors. For one thing, it was conducted at a small, private college located in the northeastern part of the United States. Applicability of the findings to other sizes, locations and types of colleges and universities needs to be tested. Second, the sample was a cross-sectional convenience. Students in select classes were asked to complete the survey. In the 2004 survey students were predominantly, but not exclusively, from the business school. In the 2007 survey, students were exclusively from the business school. In addition, the 2007 sample was smaller in size than the 2004 sample. These limitations need to be addressed in future studies by extending the research to other sizes, types and locations of colleges and universities and by using a random and more representative sampling technique.

Third, the definition of a major as a new major spanned a period of ten years during which the major could have been launched. Erosion in the newness may have been more severe in some of the new majors than in others. The classification of major as a business, communication, science or education major may also affect the innovativeness. In our study we did not differentiate between the different majors, but pooled them in the study. It is quite possible that a new business major may have a more direct impact on the relative advantage of getting a better job than a non-business major. This limitation needs to be addressed in future studies by separately analyzing the launch of new majors in the business and non-business areas of study.

\section{CONCLUSION}

Based on study results, only two of the perceptions-Trialability - New Major Course Prerequisite and Uniqueness of the new major characteristics-persisted over time, while Observability - Career related became worse from 2004 to 2007. The study provides evidence that many of the innovation characteristics don't persist and raises several interesting areas for investigation. Despite the study findings that the perceptions of the educational programs don't persist, many of the programs continue with strong enrollments. Therefore are there other characteristics that may be of importance to students in maturing, older programs? Also has the type of student enrolling in the once new educational programs changing from innovators to late adopters? Have the student innovators moved on to new, recently launched, educational programs of their preference and excitement for newness? These research questions are of growing importance to educational institutions and service businesses as they seek ways to succeed in the current difficult economic conditions. This study also raises the understanding of researchers of the permanence of innovation perceptions for educational programs.

\section{AUTHOR INFORMATION}

Joseph B. O'Donnell, Ph. D., CPA, CISA, is currently an Associate Professor of Accounting Information Systems at Canisius College. He received his Ph.D. and MBA from the State University of New at Buffalo and an undergraduate degree from the University of Notre Dame. He has taught in Latvia. He has published articles in a variety of journals including the Journal of Electronic Commerce in Organizations, Journal of Marketing for Higher Education, and Review of Business Information Systems. His research interests include diffusion of innovation, continuous auditing, Ecommerce, and accounting information systems education. 
Paul Sauer is a Professor of Marketing in the Department of Management/Marketing at Canisius College in Buffalo, New York. His received his PhD from The Ohio State University. He has taught in China and Latvia. His research interests include new product strategy, innovation management and consumer behavior. His work has been published in a variety of journals including the Journal of Consumer Research, the Journal of the Academy of Marketing Science, and the Journal of Higher Education Marketing. He has collaborated with his current coauthor on research involving the impact of launching new majors on student retention.

\section{REFERENCES}

1. Adomavicius, G., Bockstedt, J., Gupta, A., \& Kauffman, R. (2008, December). Making Sense of Technology Trends in the Information Technology Landscape: A Design Science Approach. MIS Quarterly, 32(4), 779-809. Retrieved January 26, 2009, from Business Source Premier database.

2. Alpert, Frank H. and Kamins, Michael A., (1995). "An Empirical Investigation of Consumer Memory, Attitude and Perceptions Toward Pioneer and Follower Brands.” Journal of Marketing, 1995 Volume 59 Number 4 (October), 34-45.

3. Dewett, T., \& Williams, S. (2007, March). Innovators and Imitators in Novelty-intensive Markets: A Research Agenda. Creativity \& Innovation Management, 16(1), 80-92. Retrieved January 26, 2009, doi:10.1111/j.1467-8691.2007.00421.x

4. Frank, K. A., Zhao, Y., and Borman, K. 2004. "Social Capital and the Diffusions within Organizations: The Case of Computer Technology in Schools." Sociology of Education 77: 148-71.

5. Ghemawat, P. (1991, Spring91). Market Incumbency and Technological Inertia. Marketing Science, 10(2), 161. Retrieved January 26, 2009, from Business Source Premier database.

6. Golda, J., \& Philippi, C. (2007, May). Managing New Technology Risk in the Supply Chain. Intel Technology Journal, 11(2), 95-104. Retrieved January 26, 2009, from Business Source Premier database.

7. Gomes, L. \& Murphy J. (2003). “An Exploratory Study of Marketing International Education Online.” International Journal of Educational Management Volume 17, Number 3, 116-25.

8. Henderson, G., Iacobucci, D., \& Calder, B. (2002, January). Using Network Analysis to Understand Brands. Advances in Consumer Research, 29(1), 397-405. Retrieved January 26, 2009, from Business Source Premier database.

9. Klepper, S. (1996, June). Entry, Exit, Growth, and Innovation over the Product Life Cycle. American Economic Review, 86(3), 562-583. Retrieved January 26, 2009, from Business Source Premier database.

10. Martin, C.R. and Horne, D.A. 1993. "Service Innovation: Successful versus Unsuccessful Firms." International Journal of Service Management 4(1): 49-66.

11. Mashey, J. (2009, January). The Long Road To 64 Bits. Communications of the ACM, 52(1), 45-53. Retrieved January 26, 2009, from Business Source Premier database.

12. Miles I., N. Kastrinos, K. Flannigan, R. Bilderbeek, P. der Hertog, W. Hunting and M. Bowman. 1994. Knowledge-intensive Business Services: Their Roles as Users, Carriers, and Sources of Innovation. Manchester: PREST.

13. Mutschler, A. (2008, August 25). Intel turbo charges future Core processors. Electronic News (10616624), 54(34), 9-9. Retrieved January 26, 2009, from Business Source Premier database.

14. O'Donnell, J. and Sauer, P. L. (2008) “Investigating Permanence of Perceptions of New Academic Majors' Innovative Characteristics", Proceedings of the 2008 Business Research Consortium of Western New York, Niagara University, 339-358.

15. Ostlund, L.E. 1974 "Perceived Innovation Attributes as Predictors of Innovativeness." The Journal of Consumer Research 1(2): 23-29.

16. Ready, P. M. (1992). "The Diffusion of New Math.” Paper presented at the Seventy-fifth Annual Meeting of the Association for Education in Journalism and Mass Communication, Montreal, Quebec, Canada August 5-8.

17. Reidenbach, R.E. and Moak, D.L. 1986. "Exploring Retail Bank Performance and New Product Development: A Profile of Industry Practices.” The Journal of Product Innovation Management 3(3): 187196.

18. Reinganum, J. (1985, February). Innovation and Industry Evolution. Quarterly Journal of Economics, 100(1), 81-99. Retrieved January 26, 2009, from Business Source Premier database. 
19. Rettie, Ruth, Hiller, Simon, and Alpert, Frank (2002). "Pioneer Brand Advantages with UK Consumers." European Journal of Marketing, 2002 Volume 36 Number 7/8, 895-911.

20. Roehrich, G. 2004. Consumer Innovativeness Concepts and Measurements. Journal of Business Research. 57: 671-677.

21. Rogers, Everett M. (2003). Diffusion of Innovations, 5th ed. New York, New York: Free Press.

22. Sauer, Paul L. and O’Donnell Joseph B. (2006). "The Impact of New Major Offerings on Student Retention." Journal of Marketing for Higher Education, Volume 16, Number 2, 135-155.

23. Sauer, P. L. and O’Donnell, J. B. (2007), "Innovation Constructs: An Exploratory Study," Journal of College Teaching and Learning, 4 (1), 33-44.

24. Schmidt, G., \& Druehl, C. (2005, Fall2005). Changes in Product Attributes and Costs as Drivers of New Product Diffusion and Substitution. Production \& Operations Management, 14(3), 272-285. Retrieved January 26, 2009, from Business Source Premier database.

25. Sethi, R., Smith, D.C. \& Park C.W. (2001). “Cross-functional Product Development Teams, Creativity, and the Innovativeness of New Products.” Journal of Marketing Research, Volume 38, Number 1, 73-85.

26. Munthree, S. Bick, G. and Abratt, R. (2006). A framework for brand revitalization through an upscale line extension. The Journal of Product and Brand Management, 15(3), 157-167. Retrieved March 9, 2009, from ABI/INFORM Global database. (Document ID: 1073467471).

27. Shapiro, A. (2006, November). Measuring Innovation: Beyond Revenue From New Products. Research Technology Management, 49(6), 42-51. Retrieved January 26, 2009, from Business Source Premier database.

28. Sood, A., \& Tellis, G. (2005, July). Technological Evolution and Radical Innovation. Journal of Marketing, 69(3), 152-168. Retrieved January 26, 2009, from Business Source Premier database.

29. Starbuck, William H. 1992. Learning by Knowledge-intensive Firms. Journal of Management Studies. 29 (6): 713-740

30. Theoharakis, V. \& Wong, V. (2002). "Marking high-technology market evolution through the foci of market stories: the case of local area networks." Journal of Product Innovation Management. 19 (6): 400411.

31. Wollons, R. (2000). “On the International Diffusion, Politics, and Transformation of the Kindergarten.” In Roberta Wollons (Ed.), Kindergarten and Cultures: The Global Diffusion of an Idea, 1-15, New Haven, Connecticut: Yale University Press. 
NOTES 